\title{
APPRECIATION IN JAKARTA POST'S ARTS AND CULTURAL NEWS: APPRAISAL PERSPECTIVE
}

\author{
Soraya Grabiella Dinamika \\ University of Sumatera Utara \\ soraya.dinamika@gmail.com
}

\begin{abstract}
This research explored the attitudinal meaning, subsumed under the notion of appreciation by means of appraisal theory (Martin \& White, 2005) used in the arts and cultural news discourse which retrieved from the Jakarta Post online site. This research employed qualitative descriptive method. The data of this research was obtained from the whole appreciation items found in the five arts and cultural news discourse. The objectives of this research were twofold: (a) to identify the lexical strategies conveyed by the news writer, and (b) to examine how appraising items reflect the news writer's attitude towards the news discourse. The results revealed that the writer used both positive and negative evaluation items. The data conveyed that the writer predominantly used positive appraising items with account for $80.89 \%$ in which valuation constituted of $47 \%$, followed by reaction (23.47\%) and composition (10.43\%). Meanwhile, the writer used negative appraising items with account for $19.11 \%$ in which valuation constituted of $12.17 \%$, followed by reaction $(5.21 \%)$ and composition $(1.73 \%)$. The predominant appraising items applied in the arts and cultural news, conveyed that the writer tend to use positive evaluation items to appreciate arts and cultural news as newsworthy phenomenon which has aesthetical value for the readers to read.
\end{abstract}

Keywords: Appreciation, Appraisal Theory, Arts and Cultural News.

\section{Introduction}

In this era of advanced technology, mass media has largely impacted people's interpretation towards the world around them. Mass media may vary in content, such as, news, advertisement, stories and etc. Bednarek (2006:5) states that media language is very complex in terms of its socio-economic and communicative context. The language which is used would convey the news writer's intention, message, and mission by presenting the material in the content of media. The complexity of news which is offered by media turns news as an important part of people's life. Martin \& White (2005:73) argue that news is regarded as positive appreciation, since it is used to refer to newsworthy information that is valuable enough to print. Therefore, the presence of newspaper is highly demanded nowadays. The newspaper is published in the form of two, printed and online.

Newspaper provides the readers with a lot of interesting issues of the world, such as, social, economic, politic, lifestyle, culture and art. Arts and cultural issue has become particular news which can always successfully attract 
the news reader's attention. Since art and culture are the crucial elements which contribute on the establishment of Indonesia as a multicultural country. Most of the arts cultural news offers the readers wondrous objects and fascinating facts of the richness of Indonesian's culture. Tomasouw (1986:2) defines culture as the ideas, customs, skills, arts and tools which characterize a given group of people in a given period of time. Besides, arts and cultural issues which are expanded day by day and widely spread in the society, appointed to be one of the news section in the largest English newspaper in Indonesia, The Jakarta Post. The Jakarta Post is a daily English newspaper which is published daily in the form of printed and also online. As the source of news data, the researcher chose the online one, for three considerations; the online news can be accessed easily and simply, the online news are presented real time and up to date, and only the popular and most viewed news are being presented on the online site.

Concerning about the discourse, rhetoric and communicative effect of a discourse, Appraisal has adopted interpersonal as the social metafunction of language which is extended from Systemic Functional Linguistics constructed by M.A.K Halliday \& Matthiessen (1994/2004). Appraisal is realized as discourse semantic since it emphasizes the meaning beyond the clause. As a tool of language of evaluation, appraisal, by presenting the material, reveals the speaker/writer negotiation of feelings and values to whom they communicate. Martin and Rose (2003:7) draw appraisal system under the notion of interpersonal meaning which concerns with evaluation of attitudes that are negotiated in a text, how the people express their strength of feelings and ways in which values are construed. Attitude as Martin and White (2005:35) explain, concerns with our feelings, including emotional reactions, judgements of behavior and evaluation of things. Attitude itself divided into three regions of feeling, 'affect (positive and negative feeling)', 'judgement (attitudes towards behaviour)' and 'appreciation (evaluation of semiotic and natural phenomena)'. Thus, this research would focus only on subdivision of attitude, appreciation. As appreciation construes aesthetic evaluation of natural phenomena, in which the researcher chose arts and cultural news discourse, in this case.

Thus, this research aimed at exploring the appreciation by means of Appraisal Theory used in the arts and cultural news which retrieved from the Jakarta Post online site. The objectives of this research were twofold: (a) to identify the lexical strategies conveyed by the news writer, and (b) to examine how appraising items reflect the news writer's attitude towards the news discourse.

\section{Appraisal Theory}

Appraisal as a language of evaluation (Martin, 2000; Martin \& Rose, 2003; Martin \& White, 2005) is a recent theory which has grown within the Systemic Functional Linguistic (Halliday 1994/2004). In perceiving language, SFL identifies three modes of metafunction, namely the textual, the ideational and the interpersonal. Appraisal theory adopts the interpersonal metafunction which concerns the negotiation of social relations; how people are interacting, including sharing their feelings (Martin \& Rose, 2005:7). 
Appraisal itself is developed with three main systems - attitude, engagement and graduation. Attitude deals with ways of feeling. Engagement deals with sourcing attitudes and the play of voices around opinions in discourse. Meanwhile, graduation deals with gradability. Each system is constructed with certain subsystems. An overview of these appraisal systems is presented as figure 1 below (fetched from Martin \& White, 2005:38).

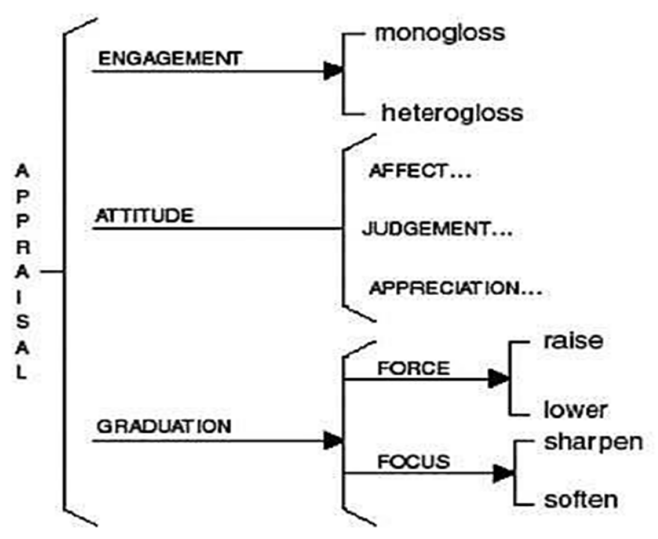

Figure 1. An Overview of Appraisal System

Attitude is the most common studied among two other systems within Appraisal theory. The grammatical realization for attitude is adjectival. Attitude itself is divided into three regions of feeling, affect, judgement and appreciation. Affect is concerned with positive and negative emotion one feels. Judgement deals with one's attitude toward behaviour. Appreciation is concerned with evaluation of entities. Since this research focused only on the appreciation one, then the terms of appreciation were broadly used.

Martin \& White (2005: 56) states that appreciation construes the positive and negative evaluation of 'things' and natural phenomena - what such things are worth (how we value them). Appreciation is generally subtyped into reaction (affection to things), composition (perception/ view of order) and valuation (cognition). Reaction is divided into impact and quality, whereas composition is then divided into balance and complexity. Speakers and writers are commonly considered as the source of evaluations. The person who is feeling something called 'as the appraiser', whereas the thing or activity is being reacted to is called as 'the appraised'. For appreciation, a mental process ascribing an attitude to a thing can be used as a diagnostic. Appreciation targets things, whether concrete or abstract, material or semiotic.

\section{Research Method}

The source of news discourse data was five arts and cultural news which retrieved from The Jakarta Post online site. The data were taken from two weekpublishing site, $3^{\text {rd }}$ December 2015 to $17^{\text {th }}$ December 2015. The five news were respectively entitled, "UNESCO recognizes nine Balinese dances", "Future of dance unmasked", "Indonesia on show in Glasgow", "Gateway to Jakarta's 
Chinatown revitalized', "Waxwork museum opens in Ancol". The whole appraising items, regarded to appreciation, which found in the five news, were taken as the data in this research.

This research employed qualitative descriptive approach. The qualitative one is used is to explore the appraising items embedded in the news discourse, whether positive or negative evaluation. Meanwhile, descriptive method was employed do describe the realization of the appraisal devices found in the text. The processes of analysis were described respectively as; firstly, read all the text to gain enough understanding about the content of the text; secondly, identified and marked any appraising items that realized appreciation items; thirdly, classified the marked items under the subtypes of appreciation whether reaction, composition or valuation; fourthly, these items were analyzed and evaluated to see the lexical strategies applied by the news writer; and finally, the results of the analysis were used to interpret and to draw the conclusion of news writer's attitude towards the news discourse.

\section{Findings and Interpretation}

The finding of data showed that by counting those five arts and cultural news consisted of 2626 words. As stated in the former section that this research aimed to explore the lexical strategies conveyed by the news writer in his news discourse, thus, only the appreciation items were taken as the data of analysis. Furthermore, there was 115 occurrences represented the appreciation items. These words then were tabulated under each subtypes of appreciation. The table 4.1 below showed the frequency of appreciation items' occurrences which reflected the reaction subtype found in the five arts and cultural news discourse.

Table 4.1 Frequency of Reactions' Occurrences

\begin{tabular}{|c|c|c|c|c|c|c|c|}
\hline \multicolumn{8}{|c|}{ Reaction } \\
\hline \multicolumn{4}{|c|}{ Impact } & \multicolumn{4}{|c|}{ Quality } \\
\hline+ Item & Freq. & - Item & Freq. & + Item & Freq. & - Item & Freq. \\
\hline Epic & 1 & Usually & 1 & Flickering & 2 & Plain & 1 \\
\hline Former & 3 & Too excited & 1 & Brightly & 1 & & \\
\hline Luminary & 1 & Former & 3 & Fine & 2 & & \\
\hline Dramatic & 1 & & & Delicate & 1 & & \\
\hline Vibrant & 1 & & & Excellent & 1 & & \\
\hline Diverse & 1 & & & Beautifully & 1 & & \\
\hline Fascinating & 1 & & & Beautiful & 1 & & \\
\hline Eye opening & 1 & & & Smoothly & 1 & & \\
\hline Great & 1 & & & Best & 3 & & \\
\hline Interesting & 1 & & & Finest & 1 & & \\
\hline Positive & 1 & & & & & & \\
\hline Total (+) & 13 & Total (-) & 5 & Total (+) & 14 & Total (-) & 1 \\
\hline
\end{tabular}

As shown in the table above, reaction construed 27 occurrences of positive appraising items and 6 negative evaluation items. The result showed that reaction 
subtype was dominated by positive appraising items. Meanwhile, the table 4.2 below showed the frequency of appreciation items' occurrences which reflected the composition subtype found in the five arts and cultural news discourse.

Table 4.2 Frequency of Compositions' Occurrences

\begin{tabular}{|c|c|c|c|c|c|c|c|}
\hline \multicolumn{8}{|c|}{ Composition } \\
\hline \multicolumn{4}{|c|}{ Balance } & \multicolumn{4}{|c|}{ Complexity } \\
\hline + Item & Freq. & - Item & Freq. & + Item & Freq. & - Item & Freq. \\
\hline Balanced & 1 & & & Prestigious & 1 & Exaggerated & 1 \\
\hline Bulging & 1 & & & Precisely & 1 & Tiny & 1 \\
\hline Controlled & 1 & & & Richness & 1 & & \\
\hline & & & & Rich & 2 & & \\
\hline & & & & Modestly & 1 & & \\
\hline & & & & Very detailed & 1 & & \\
\hline & & & & Highly detailed & 1 & & \\
\hline & & & & Simply & 1 & & \\
\hline Total (+) & 3 & Total (-) & 0 & Total (+) & 9 & Total (-) & 2 \\
\hline
\end{tabular}

The result showed that composition construed 12 positive appraising items and 2 negative appraising items. Therefore, it proved that composition subtype was also dominated by positive appraising items. At last, table 4.3 below showed the frequency of appreciation items' occurrences which reflected the valuation subtype found in the five arts and cultural news discourse.

Table 4.3 Frequency of Valuation' Occurrences

\begin{tabular}{|c|c|c|c|}
\hline \multicolumn{4}{|c|}{ Valuation } \\
\hline+ Item & Freq. & - Item & Freq. \\
\hline New & 2 & Ancient & 1 \\
\hline Deep & 1 & Smattering & 1 \\
\hline Young & 1 & Unexpected & 1 \\
\hline Younger & 3 & Classical & 1 \\
\hline Innovation & 2 & Classic & 1 \\
\hline Important & 4 & Traditional & 9 \\
\hline Contemporary & 3 & & \\
\hline Creative & 8 & & \\
\hline Modern & 1 & & \\
\hline Evolution & 1 & & \\
\hline Highly-Stylized & 1 & & \\
\hline Internal & 1 & & \\
\hline External & 1 & & \\
\hline Introverted & 1 & & \\
\hline Extraordinary & 1 & & \\
\hline Semi-Sacred & 1 & & \\
\hline Originated & 1 & & \\
\hline Original & 6 & & \\
\hline
\end{tabular}




\begin{tabular}{lll}
\hline Especially & 1 & \\
\hline Long-Admired & 1 & \\
\hline Popular & 1 & \\
\hline Famous & 3 & \\
\hline Colourful & 1 & \\
\hline Essential & 2 & \\
\hline Prominent & 1 & \\
\hline Decorative & 2 & \\
\hline Impressive & 1 & \\
\hline Impressed & 2 & \\
\hline Total $(+)$ & 54 & Total $(-)$ \\
\hline
\end{tabular}

The result showed that valuation construed 54 positive appraising items and 14 negative appraising items. Therefore, it proved that composition subtype was also dominated by positive appraising items. Three of appreciation subtypes conveyed that positive evaluation exceeded the negative one. Accordingly, in order to find out the percentage of appreciation and its subtypes in the selected news discourse, percentage tabulation was formed as table 4.4 below.

Table 4.4 Percentage of Appreciation Subtypes

\begin{tabular}{lcc}
\hline $\begin{array}{c}\text { Appreciation } \\
\text { Subtypes }\end{array}$ & $\begin{array}{c}\text { Number of Positive } \\
\text { Appraising Items Occurrences }\end{array}$ & $\begin{array}{c}\text { Number of Negative } \\
\text { Appraising Items Occurrences }\end{array}$ \\
\hline Reaction & 27 & 6 \\
\hline Composition & 12 & 2 \\
\hline Valuation & 54 & 14 \\
\hline Total & 93 & 22 \\
\hline Percentage (\%) & $80.89 \%$ & $19.11 \%$ \\
\hline
\end{tabular}

The percentage showed that positive appraising items were dominantly used by the news writer in the arts and cultural news discourse. It is proven by the total number of percentage $80.89 \%$, in which positive valuation exceeded another subtypes, $47 \%$, which then respectively followed by positive reaction, $23.47 \%$ and positive composition $10.43 \%$. Meanwhile, the news writer used less negative appreciation items in the news discourse, its total number of percentage was $19.11 \%$. The negative valuation exceeded another negative subtype, $12.17 \%$, which then respectively followed by negative reaction, $5.21 \%$ and negative composition $1.73 \%$. From the number of appraising items used, it can be interpreted that the writer tends to use positive lexical strategies in the news he wrote.

\section{Conclusion and Suggestion}

Based on the analysis of the five selected arts and cultural news discourse from the Jakarta Post online site, it can be concluded that the writer of the news applied the system of appraisal covering the appreciation notion, under the attitude system. The writer evenly used both positive and negative evaluation of 
appraising items. The subtypes of appreciation which were used covered; reaction including impact and quality; composition including balance and complexity; and valuation.

While the results of the analysis of the news article based on each appreciation subtypes indicated that most of the evaluation fell on the positive evaluation. It was proven that positive evaluation (80.89\%) exceeded negative one (19.11\%). It can be concluded that the writer of arts and cultural news expressed his words in tendency of positive appraising items. It aimed to tell the readers that arts and cultural news is such a newsworthy phenomenon which has aesthetical value to be read and its news content is needed to be appreciated positively.

Appraisal is an interesting field to study, as it offers the audience to be more critical in evaluating the language an author/writer uses in his certain discourse. This research has contributed in the area of Systemic Functional Linguistic, particularly in language of evaluation field. It provides new insights of interpersonal meaning in the arts and cultural news discourse. To contribute more insights and findings in Appraisal Theory, further and broader research on attitude, engagement and graduation is considerably suggested to be administered on more various discourses.

\section{References}

Bednarek, M. (2006). Evaluation in Media Discourse. Analysis of a Newspaper Corpus. London and New York: Continuum.

Halliday, M.A.K. (1994). An Introduction to Functional Grammar. 2nd edn. London: Edward Arnold.

Martin, J. R., \& David Rose. (2003). Working with Discourse-meaning beyond the clause. London: Continuum.

Martin, J.R. \& White, P. (2005). The Language of Evaluation: Appraisal in English. London and New York: Palgrave Macmillan.

Tomasouw, Pauline. (1986). Cross Cultural Understanding. Jakarta: Penerbit Karunika.

Wigunadi, Mohamad. 2014. Appraisal in the Jakarta Post Articles on National Examination. English Education Journal. Semarang: Universitas Negeri Semarang. 53-58.

Sudrutai, Arunsirot. (2012). The Use Of Appraisal Theory To Analyze Thai Newspaper

Commentaries. MANUSYA: Journal of Humanities Regular. 70-89.

www.thejakartapost.com 